Rev. Latinoam. Psicopat. Fund., São Paulo, v. 11, n. 2, p. 336-338, junho 2008

O ser interior na psicanálise

Walter Trinca

São Paulo: Vetor, 2007, 378 págs.

\title{
O ser interior na psicanálise
}

Maria Izilda Soares Martão

O autor, por meio do referencial psicanalítico e da prática clínica, explicita noções para a compreensão do "ser interior" que é tema central do livro: O ser interior na psicanálise. O "ser interior" é descrito como um "núcleo essencial", um "potencial de existência" que o indivíduo possui e que lhe imprime singularidade e unicidade.

Metaforicamente, pode-se pensar no "ser interior" como uma espécie de "DNA psíquico" que acompanha o indivíduo em sua existência e se expressa como energia vital, flexível, passível de influenciar o self a promover mudanças e adaptações favoráveis à vida, sem fugir de sua essência: o ser genuíno que habita o interior de cada pessoa. Apesar de o "ser interior" estar alicerçado por forças vitais e ter como metas: promover o desenvolvimento emocional, a integração e o bem-estar do ser, nem sempre dá conta de cumprir suas funções. A interlocução entre o "ser interior" e o self é permeada pelo grau de contato que se estabelece entre ambos. Por sua vez, o grau de contato 
depende da estruturação do self, que está atrelada à influência de outros fatores: o ambiente, as relações de objetos, a intolerância, a frustração, a supressão de emoções e outros. São descritas três formas de contatos entre self e ser interior: oclusivo, inconsciente e consciente. Para cada forma, há uma escala com níveis que variam de alto a baixo e são determinantes sobre o desenvolvimento psíquico e as patologias do indivíduo.

O self é descrito como instância psíquica fundamental que contém os elementos que compõem a personalidade, mas não contém o núcleo da existência genuína do indivíduo. Assim, o protagonista da existência é o "ser interior", e o self atua como coadjuvante principal na formação da personalidade. Ele é o mediador entre o "ser interior" e as forças pulsionais, principalmente aquelas relacionadas à pulsão de morte. Ao ser depositário de forças que se opõem, o self, torna-se um espaço de conflitos. Se ele permanece sob a influência do ser interior, seu desenvolvimento favorece a preservação da vida, mas se ele se submete às forças advindas da pulsão de morte, promove patologias e conflitos emocionais.

O livro abarca aspectos teóricos, dentre os quais, destacarei alguns que merecem reflexões:

O primeiro refere-se às possibilidades de o "ser interior" reassumir os centros de comando pela sua influência sobre o self e, assim, dar novos rumos para a vida do indivíduo através do afastamento das patologias e dos sofrimentos, decorrentes do distanciamento de contato.

Outro aspecto, refere-se à interlocução teórica entre "ser interior" e alguns referenciais winnicottianos: 1) O autor pressupõe que, se o "ser interior" exerce influência sobre o self, promove a integração do mesmo que, por sua vez, conduz o processo de desenvolvimento e de maturação do indivíduo. 2) O conceito de "espaço potencial", refere-se à "experiência de encontro com o próprio ser" ou, com o "ser interior", porque ambos significam espaços propiciadores para o desabrochar da criatividade. 3) A influência do ambiente e a interação com outros fatores internos para o desenvolvimento do self e do grau de contato emocional.

Trinca contextualiza a manifestação da pulsão de morte, atuando no "self", representando as partes más referidas na teoria kleiniana, dando-lhe uma denominação mais abrangente: "a constelação do inimigo interno". Esta articulação é interessante e merecedora de estudos e atenção na clínica para compreensão das configurações em que ela se expressa.

$\mathrm{O}$ autor efetua uma interlocução sobre o distanciamento de contato entre o "ser interior" e o self, e as atuais manifestações patológicas sociais decorrentes. De um lado, há o homem que supervaloriza os aspectos materiais em detrimen- 
to dos aspectos internos, e, de outro, as sociedades que se alicerçam por meio de "princípios e valores concretistas", imediatistas e antiéticos, e que concebe o homem como um "objeto de uso e de domínio". Esse homem, sentindo-se reduzido a um objeto descartável, responde à sociedade através do "embrutecimento humano", mostrando-se violento e indiferente ao outro, aos valores e aos princípios relacionados à vida.

Resumidamente, o texto tece considerações sobre o "ser interior", como fonte de luz e de vida, tendo, como aliada, a mobilidade psíquica, trabalhando em prol da integração e do desenvolvimento genuíno da vida. Porém, para que o "ser interior" obtenha êxito é necessário ter o self sob sua influência, com alto grau de contato consciente, promovendo a expansão da mente. Em contrapartida, surge um oponente poderoso: "a constelação do inimigo interno", como subproduto da pulsão de morte, tentando submeter o self para torná-lo obscuro e afastá-lo do contato com "ser interior", e destruir os aspectos genuínos, levando o indivíduo a adoecer.

A descrição psicodinâmica entre as instâncias do "ser interior", do self e da "constelação do inimigo interno" são referendadas por Bion, Freud, Klein, Winnicott e outros nomes de reconhecimento na psicanálise, promovendo uma interlocução teórica que convida o leitor a rever alguns conceitos psicanalíticos: pulsões de morte, partes internas más, o núcleo do self, mecanismos de defesa e outros, sob um olhar mais abrangente.

A proposta de "um sistema geral unificado", que tem como núcleo o "ser interior" e que retrata a interação deste com os demais elementos da personalidade total, percorrendo um caminho que expressa de um lado a saúde, a liberdade e a legitimidade do ser e, de outro, o comprometimento psíquico, permite efetuar uma integração entre a teoria e a clínica. Assim, esse livro é uma contribuição teórica e uma proposta clínica que possibilita um panorama psíquico global do indivíduo, retratando seus aspectos saudáveis, seus recursos, suas dificuldades e seu sofrimento. Permite também ao paciente, conhecer seu sistema mental determinante e afastar seu sofrimento pela apropriação de suas forças genuínas.

\section{Maria IzILda SoARes Martão}

Psicóloga clínica; doutoranda pela Universidade de São Paulo (São Paulo, SP, Brasil)

Rua Rui Barbosa, 333/92-A - Boa Vista

09190-370 Santo André, SP, Brasil

Fone: (11) 4990-1300

e-mail: soaizi@hotmail.com 